\title{
A COCOON IN A FOREIGN LAND: VASSANJI'S SHORT FICTION
}

\section{Dr. Aditi Vahia}

\begin{abstract}
In the 'Foreword' to his collection Uhuru Street, Vassanji observes that 'Uhuru' means 'independence'. The Kichwele Street of Dar es Salaam - later renamed as Uhuru street nurtures the spirit of independence irrespective of the continual changes that the street experienced from the sheltered innocence of colonial rule in the 1950 s to the shattered world of the 1980s.
\end{abstract}

This collection of short stories - as many of Vassanji's works is characterized by "a complex ethno-cultural identity" that incorporates multiple countries (Kenya, Tanzania, India, Canada, U.S.A.), religions (crucially, the syncretic bhakti tradition he was raised in), languages (Gujarati, English, Swahili, Hindi). , The stories in Uhuru Street explore political and social change in the city of Dar es Salaam in the East African country of Tanganyika. They follow a historical arc which begins in the years leading up to independence (in 1961) and concludes in the decade or so.

This paper analyzes the microcosm of an immigrant world as portrayed by Vassanji in his Uhuru Street through its eccentric characters giving us a portrait of a place and a people losing their innocence. The stories come together as a story of generations new and old, the former searching for a new identity, the latter, fiercely holding onto the past. We share with these people the moment of moving on, of leaving the place where we have roots, knowing that things will never be the same.

Keywords: Vassanji, Communal Cocoon, Immigrant World, Ethno-Cultural Identity 
In the 'Foreword' to his collection Uhuru Street, Vassanji observes that 'Uhuru' means 'independence'. The Kichwele Street of Dar es Salaam - later renamed as Uhuru street nurtures the spirit of independence irrespective of the continual changes that the street experienced from the sheltered innocence of colonial rule in the 1950s to the shattered world of the 1980s.

This collection of short stories - as many of Vassanji's works is characterized by "a complex ethno-cultural identity" that incorporates multiple countries (Kenya, Tanzania, India, Canada, U.S.A.), religions (crucially, the syncretic bhakti tradition he was raised in), languages (Gujarati, English, Swahili, Hindi). ,. They follow a historical arc which begins in the years leading up to independence (in 1961) and concludes in the decade or

so.

The story of Indian Diaspora has drawn a lot attention in the last decade. Diaspora has come to play a significant and ongoing role creating for itself a niche in most of the countries it calls home. Due to its varied origin, divergent patterns of migration and settlement and different degrees of absorption and integration into the culture of their new homeland, the Indian Diaspora defies easy categorization. Thus complexity due to confluence of many discreet cultures, languages and history is an unavoidable result.

Since last few decades, countries like Canada and USA have been considered as the promised land by immigrant communities from all over. They are countries which shelter a variety of communities. Among these, a considerable portion is peopled by characters who have left their settings, displacing themselves, to surrender the familiar and to relocate themselves in these 'Promised Land'. However, it is not as simple a matter as adapting to a new environment or adjusting to a new way of life but it is adopting a new identity. It is this fact that often turns the diasporic experience into an acute unavoidable agony.

The diasporic writings, also known as 'expatriate writings' or 'immigrant writings' largely give voice to the personal experiences of the writers, which are the results of the clash of multiple cultures. Consequently, postcolonial literature by diasporic writers covers a wide variety of emotional experiences which are formed with the prominent components 


\section{Dr. Aditi Vahia/ Page 1-9}

such as alienation, assimilation, displacement, adaptation, diaspora, second generation migrant, deracination, alterity, indigeneity, nationhood, imagining homeland, identity, ethnicity/culture, exoticisation, history/memory, etc. Every major diasporic writers including Raja Rao, V. S. Naipaul, Satyendra Nandan, Salman Rushdie, Vikram Sheth, M. G. Vassanji, Rohinton Mistry, Bharati Mukherjee, and Jhumpa Lahiri ( to name a few) write about people and their lives which are distinct not only to their homelands but have the fragrance of their host country. However, those who have been able to identify themselves with their new geographical environment procured the bi-cultural perception which equips them to write from a wider and more exciting angle.

According to Cohen, diasporic communities have shown a continuing or newly asserted attachment to places of origin. This has generated many attempts at using diaspora for the purpose of homeland economic and social development, sometimes in cooperation with $\mathrm{h}$ international development agencies and the governments of rich countries. At the same time the idea of 'homeland' and 'home' are intrinsic to the diasporic condition has been questioned. Diaspora is different from travel (though it works through travel practices) in that it is not temporary. It involves dwelling, maintaining communities, having collective homes away from home (and in this it is different from exile, with its frequently individualistic focus) (Global). 'Thus the term Diaspora is a signifier, not simply of transnationality and movement, but of political struggles to define the local, as distinctive community, in historical contexts of displacement' (Clifford 308), and as Sandhya Shukla remarked, "... homeland, land of settlement, space for travel, all undergo significant reworking through the concept and object of diaspora" (551).

Stephen Gill states in his essay 'Mythical Interpretation of Indo-Canadian Diaspora' observes that the word Diaspora is not a substitute for the word immigrant. Diaspora essentially is a bitter experience of dislocation that leads to alienation, a sense of loss and nostalgic desires. It refers to that particular class of immigrants who are unable to go back, primarily because of the hostile climate of discrimination in the country of birth. The hostile climate is intolerable in the land of birth and tolerable in the land of adoption. Usually Diasporans are not happy anywhere, and suffer silently since the issue of identity is never resolved and remains to an ongoing process. 
Interestingly, the present use of the term Indian Diaspora, particularly when it refers to Indo-Canadian writers, is loaded with confusion. Its overuse conflicts with words like immigrant, visitor, racial minorities, ethnic groups, refugee, new Canadian, workers, expatriates, travellers, and other categories.

Though it is very common to use the terms 'expatriation' and 'immigration' as synonyms, it is also necessary to draw a line of demarcation between the two, however thin it may be. Expatriation focuses on the native land that has been left behind while immigration denotes the country into which one has ventured as a new citizen. While the former reflects the state of exclusion, the latter celebrates his presence in a new country. In any case, the writer of Diaspora negotiates a new literary space giving voice to both these sensibilities. In subtle and sensitive ways the writers of Diaspora bring to the international literary consciousness the live experience of Diasporic communities scattered across the globe. It is literature to which children of Diaspora can relate and of which they are justly proud.

While discussing the issue of cultural identity, Stuart Hall, in 'Cultural Identity and Diaspora' states ,"... instead of thinking of identity as an already accomplished fact, which the new cultural practices..., we should think ... of identity as a 'production' which is never complete, always in process and constituted within, not outside representation" (110). Considering this, identity is an issue of 'becoming' and not 'being'.

In the last twenty years, the Indian diaspora seems to have come of age. Shedding its minority status, it has presented it inclination for a majority, not in the sense of numerical superiority, but of growing up, maturing and attaining self-apprehension and self-expression.

While this fact can be generalized for the entire human race, it becomes an essentiality in case of the immigrant community across the globe. These are the people "in diaspora", as reflected by Makarand Paranjpe in his In Diaspora. They represent a amalgamation of six features i.e. 'dispersal', 'collective memory', 'alienation', 'respect 


\section{Dr. Aditi Vahia/ Page 1-9}

and longing for the homeland', 'a belief in restoration', and finally 'self-definition in terms of the present homeland'. What emerges then is the 'total self' - influenced by all these features. Above all, there is this desperate need of wanting to be accepted by the mainstream society. Thus the issue of identity for a person of diaspora remains problematic and always contested. Having grown up in the two worlds simultaneously, the issue of identity is a complex one as they have undergone a process of being culturally uprooted and 're rooted'.

This multiplicity of an immigrants' identity is expressed by Sura P. Rath in 'Home(s) Abroad: Diasporic Identities in Third Spaces' :

Call me American. Having lived in the United States of America since August 31, 1975 -- first as a 'non-resident alien' student ( $F-1)$ and then as a trainee $(\mathrm{H}-1)$, as a permanent resident ('resident alien' or holder of the coveted 'Green Card'), and finally as a naturalized citizen -- with papers documenting my legal entry and continued stay, I have never had any doubt about my immigrant identity. (25) He further makes a case for the inseparableness of geography and identity when he says :

the most common manifestation of one's other-ness in an alien culture is a question one encounters from time to time: 'where are you from?', not 'who/what are you?' Its follow-up is often 'No, I mean where you are really from.' An explanation of one's being ' by origin/birth' leads to an ambivalent rejoinder such as 'what brought you here from there?' signifying sometimes a naive curiosity but oftentimes a resigned resentment. Such encounters, common I should say for people of Indian diaspora in the United States but perhaps also for immigrants in countries such as the United Kingdom or Canada. (26)

Thus after trying hard to be part of the mainstream culture, all get gain is "resigned resentment" which becomes perhaps an integral part of their psyche. The writers of diaspora address this problem in different ways. Born in London and raised in Rhode Island, Jhumpa Lahiri,the Indian-American writer feels that for immigrants, the challenges of exile, the loneliness, the constant sense of alienation, the knowledge of and longing for a lost world, are more explicit and distressing than for their children. The 
problem for the children of immigrants, those with strong ties to their country of origin, is that they feel neither one thing nor the other.

Along with Indo-Canadian and Indo- American diaspora, another significant voice in this field is that of Indo-Caribbean diaspora. In fact, Hall in his essay "Negotiating Caribbean Identities" observes that the Caribbean is the first, the original and the purest diaspora for everybody there comes from somewhere else. He also feels, "the way Caribbeans negotiate their identities has a message for the rest of the world ... for wherever one finds diasporas one always finds precisely those complicated processes of negotiation and transculturation which characterize Caribbean culture." One important voice in this field is M. G. Vassanji.

While tracing the history of the Indian migration to the Caribbean in 'Introduction' to Jahaji, Frank Birbalsingh observes that four lakh Indians came under contract to the Caribbean between 1834 and 1917 and replaced black labour force and occupied the lowest rung of the ladder in Trinidad. This was a period of great political turmoil and instability resulting in a serious rivalry between the Indo-Caribbean and Afro-Caribbean desire for the political power. Consequently, there was a large wave of Indo-Caribbean migration to Britain, Canada and the United States in the decade of 1970s.

It is these political and social changes in the city of Dar es Salaam in the East African country of Tanganyika which provide a thematic base to the short story collection Uhuru Street by M. G. Vassanji. Vassanji's other books include the acclaimed novels The Gunny Sack, No New Land (1991) and Amriika (1999). His unique place in Canadian literature comes from his elegant, classical style, his narrative reach, and his interest in characters trying to reconcile different worlds within themselves. The subtle relations of the past and present are also constants in his writing. With delicate strokes, and with irony and humour, M.G. Vassanji brings alive the characters who live and work in the shops and tenements of Uhuru Street.

The stories come together as a story of generations new and old, the former searching for a new identity, the latter, fiercely holding onto the past. We share with these people 
the moment of moving on, of leaving the place where we have roots, knowing that things will never be the same. As the author states in the 'Forward' "Once upon a time Uhuru Street was called Kichwele Street. The change marked a great event in the country.... Over the years Uhuru Street changed its looks; so did Dar, so did the country. The stories in this volume are about the Indians of Uhuru Street during these years of change". Thus he presents a microcosm of an immigrant world through its eccentric characters giving us a portrait of a place and a people losing their innocence. The stories come together as a story of generations new and old, the former searching for a new identity, the latter, fiercely holding onto the past. We share with these people the moment of moving on, of leaving the place where we have roots, knowing that things will never be the same. In the process, he offers a communal cocoon while depicting the changes in Uhuru Street from the sheltered innocence of colonial rule in the 1950 s to the shattered world of the 1980s.

With delicate strokes, and with irony and humour, M.G. Vassanji brings alive the characters who live and work in the shops and tenements of Uhuru Street. Among a cast of vividly portrayed characters are: Roshan Mattress, so called because of her free and easy ways; Baby, the blubbery-fat daughter of a grocer, indulged but amiable; Ahmed, the street-wise orphan fighting for survival; Alzira, a young Goan dressmaker, who gaily entertains her employers with local gossip; a servant, Ali, who opens up the world for the children in his charge, until he oversteps his bounds and abruptly has to leave; and Zarina, tantalizingly lithe and gentle, who fills Baby's husband, Black, with longing. In Vassanji's deft hands, the street itself breathes life, and symbolizes the comradeship of this immigrant community. The stories take us from the late colonial days of the 1950s through to the 1980s when many of the characters have moved away from the confines of their community only to find that hopes and aspirations are displaced by harsh realities, and the spirit that was Uhuru Street is no more than a nostalgic dream.

About half of he stories in the collection are narrated in first person, thereby implying a personal identity crisis while the remainder of the stories are recounted mainly from a third person viewpoint displaying a range of subjects and consciousness. This makes 


\section{Dr. Aditi Vahia/ Page 1-9}

them a kind of people's history which is highly personal. There is a group of stories that outlines, in Bardolph's words, "sensual retracing of moments of childhood" (85). A distinct way of life emerges through the stories as the child narrators watch the neighbours across the road, the family upstairs, the shopkeepers and so on. Uhuru Street , thus provides "narratives and comments on its own history: legends are shown in the making as gossips circulate, judgements are passed. ... the street is busy constructing its own myth" (Bardolph, 85).

Broadly, the stories in the collection may be categorized into three thematic groups : stories that analyze intracommunity dealings, others that throw light on interracial relations and finally those which go beyond the boundaries of Uhuru Street to depict the process of immigration and adaption to another world. After all is said and done, Uhuru Street has been home for many lost souls, the only home they had known. This fact is apparent particularly in the concluding story "The London Returned" where the protagonist realizes that distance created by emigrating had heightened the sense of rootlessness. He feels' "Yes, when it comes down to it, there is only a plain longing for home, a permanence" (139).

To conclude one can say that for the South Asians in Africa, the sustaining of the communal cocoon becomes a strategy for survival in a land that is not theirs. Through his wonderfully drawn, often eccentric characters, Vassanji gives us a portrait of a place and a people losing their innocence. The stories come together as a story of generations new and old, the former searching for a new identity, the latter, fiercely holding onto the past. We share with these people the moment of moving on, of leaving the place where we have roots, never to return. 


\section{Works Cited}

Birbalsingh, Frank. Ed. Jahaji: An Anthology of Indo-Caribbean Fiction. Toronto: TSAR Publications, 2000. Print

Clifford, James. "Diasporas." Cultural Anthropology 9.3 (1994): 302-338.

Blackwell Publishing. Web. 7 January 2014.

Cohen, Robin. "Diasporas and the Nation-State: From Victims to Challengers." International Affairs (Royal Institute of International Affairs 1944-) 72.3 (1996): 507-520. Ethnicity and International Relations, Web. 21 February 2014.

Gill, Stephen. 'Mythical Interpretation of Indo-Canadian Diaspora' Immigrant. Ontario:

Vesta Publications Ltd., 1982. Print

Hall, Stuart. "Negotiating Caribbean Identities", Postcolonial Discourse .Ed.Gregory

Castle, Oxford: Blackwell Publishers, 2001. Print \& Web

Paranjape, Makarand ed. In Diaspora : Theories, Histories, Texts. New Delhi :

Indialog Publications Pvt. Ltd., 2001. Print

Rath, Sura "Home(s) Abroad: Diasporic Identities in Third Spaces" ed. Viet Thanh

Nguyen and Tina Chen. Special Issue: Postcolonial Asian America. Volume 4, Issue 3, (Spring/Summer 2000) Print \& Web

Shukla, Sandhya. "Locations for South Asian Diasporas." Annual Review of Anthropology 30 (2001): 551-572. Department of Anthropology, Columbia University, New York. Web. 7 April 2014.

Vassanji, M. G. Uhuru Street Toronto : Mclelland and Stewart Ltd.1991.

---. The Gunny Sack Kenya : Pearson Publications.1989.

---. No New Land. Mclelland and Stewart Ltd. 2012.

---. Amrika. Mclelland and Stewart Ltd. 2012.

\section{Dr. Aditi Vahia Assistant Professor Department of English The Maharaja Sayajirao University of Baroda Vadodara, Gujarat Email: aditi.vahia@gmail.com}

